\title{
Bacterial Nanocellulose Derived from Banana Leaf Extract: Yield and Variation Factors
}

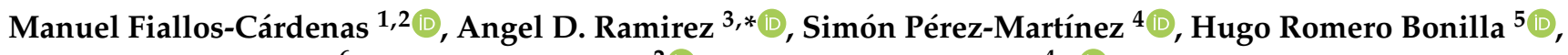 \\ Marco Ordoñez-Viñan ${ }^{6}$, Omar Ruiz-Barzola ${ }^{2}$ (1) and Miguel A. Reinoso ${ }^{4, *}$
}

1 Facultad de Salud y Servicios Sociales, Universidad Estatal de Milagro, Milagro 091050, Ecuador; mfiallosc@unemi.edu.ec

2 Facultad de Ciencias de la Vida, Escuela Superior Politecnica del Litoral, ESPOL, Campus Gustavo Galindo, Guayaquil 090902, Ecuador; oruiz@espol.edu.ec

3 Facultad de Ingeniería en Mecánica y Ciencias de la Producción, Escuela Superior Politecnica del Litoral, ESPOL, Campus Gustavo Galindo, Guayaquil 090902, Ecuador

4 Facultad de Ciencias e Ingeniería, Universidad Estatal de Milagro, Milagro 091050, Ecuador; sperezm2@unemi.edu.ec

5 Facultad de Ciencias Químicas y de Salud, Universidad Técnica de Machala, Machala 170517, Ecuador; hromero@utmachala.edu.ec

6 Facultad de Mecánica, Escuela Superior Politécnica del Chimborazo, Riobamba 060155, Ecuador; marco.ordonez@espoch.edu.ec

* Correspondence: aramire@espol.edu.ec (A.D.R.); mreinosos@unemi.edu.ec (M.A.R.)

check for

updates

Citation: Fiallos-Cárdenas, M.; Ramirez, A.D.; Pérez-Martínez, S.; Romero Bonilla, H.; Ordoñez-Viñan,

M.; Ruiz-Barzola, O.; Reinoso, M.A.

Bacterial Nanocellulose Derived from Banana Leaf Extract: Yield and Variation Factors. Resources 2021, 10, 121. https://doi.org/10.3390/ resources10120121

Academic Editor: Elena Tamburini

Received: 15 October 2021

Accepted: 24 November 2021

Published: 27 November 2021

Publisher's Note: MDPI stays neutral with regard to jurisdictional claims in published maps and institutional affiliations.

Copyright: (C) 2021 by the authors. Licensee MDPI, Basel, Switzerland. This article is an open access article distributed under the terms and conditions of the Creative Commons Attribution (CC BY) license (https:/ / creativecommons.org/licenses/by/ $4.0 /)$.

\begin{abstract}
Bananas are one of the most important crops worldwide. However, a large amount of residual lignocellulosic biomass is generated during its production and is currently undervalued. These residues have the potential to be used as feedstock in bio-based processes with a biorefinery approach. This work is based on the valorization of banana leaf and has the following objectives (i) to determine the effect of certain physical and environmental factors on the concentration of glucose present in banana leaf extract (BLE), using a statistical regression model; (ii) to obtain Bacterial Nanocellulose (BNC), using BLE $(70 \% v / v)$ and kombucha tea as fermentation medium. In addition, the physicochemical properties of BNC were evaluated by X-ray diffraction (XRD), Fourier transform infrared (FTIR), and thermogravimetric analysis (TGA). The results indicate that storage time, location, leaf color, and petiole type are factors related to BLE concentration, which is reduced by approximately $28.82 \%$ and $64.32 \%$ during storage times of five days. Regarding BNC biosynthesis, the results indicate that the highest yield, $0.031 \mathrm{~g} / \mathrm{g}$, was obtained at 21 days. Furthermore, it was determined that the highest production rate was $0.11 \mathrm{gL}^{-1} \mathrm{~h}^{-1}$ at 11 days of fermentation. By FTIR, it was determined that the purification step with $\mathrm{NaOH}(3 \mathrm{M})$ should be carried out for approximately two hours. This research supports the development of a circular bioeconomy around the banana value chain, as it presents a way of bioprocessing residual biomass that can be used to produce bioproducts.
\end{abstract}

Keywords: biorefinery; banana; nanocellulose; circular bioeconomy; valorization; sustainability; biopolymer; linear regression; bioprocesses; Kombucha

\section{Introduction}

Banana is a perennial tropical crop belonging to the Musaceae family and is one of the most important crops in the world in terms of metric tons harvested [1,2]. It is also of economic and food importance for many developing countries [3]. The banana production system generates different by-products as (i) starchy material, rejected fruits that do not reach the commercial standard [4,5], this by-product is used for the production of flour, cattle feed, or snacks; and (ii) lignocellulosic biomass: rachis, leaf, and pseudostem [2]. However, these lignocellulosic residues are usually not valorized [6-8]. Banana leaves can be used as packaging for certain foods [9], but conventionally they are left on the plantation 
ground. This practice is thought to benefit the crop; however, it has been determined that it can cause a nutritional imbalance in the plant [10], in addition to generating environmental and health problems [11,12].

On the other hand, the rachis with the banana bunches arrives at the collection center, where the banana is finally packaged. The rachis is piled up to be discarded [13,14]. It is estimated that in Ecuador, the main banana exporter worldwide, the waste/product ratio is 3.79, and the annual waste production is $2.65 \mathrm{Mt}$ of biomass on a dry basis [15]. The valorization of residual biomass based on the circular bioeconomy model would be a sustainable strategy that could generate new sources of employment, important for food security and in line with some of the Sustainable Development Goals (SDGs) [16].

For the residual biomass to be valorized, it must first pass through a pretreatment stage. The operations used in the pretreatment stage can be physical, chemical, biological, or a mixture of these [17-20]. Physical pretreatment involves using different techniques such as steam, crushing, grinding, ultrasound, microwaves, or drying. On the other hand, chemical pretreatment makes use of acidic, basic, or oxidizing reagents. In contrast, biological pretreatment is based on fungi [21] and enzymes [22-25]. The pretreatment step usually consists of solubilizing the hemicellulose structure and reducing the lignin composition of the biomass [23,26], which facilitates enzyme access to the polymers in the enzymatic hydrolysis stage of cellulose $[27,28]$. Enzymes are used to reduce the complex sugars present in the biomass, thereby increasing the concentration of simple sugars, such as glucose, galactose, arabinose, and xylose. These sugars serve as a carbon source in the fermentation stage [29-31].

Different studies demonstrate the use of this biomass to obtain (i) bioenergy, such as bioethanol [32-36], and biogas [37,38], and (ii) compounds of interest, such as biofertilizers [39,40], lactic acid [41], activated carbon [42], biopolymers [43], bacterial nanocellulose [44], among other compounds of industrial interest. In this sense, banana leaves can be used as a raw material for obtaining different bioproducts. It is mainly composed of cellulose (21.90-32.56\%), hemicellulose (25.80-12.00\%), and lignin (39.10-17.00\%), expressed as a percentage of dry weight $[35,45,46]$. Likewise, it has been determined that the total phenolic content is $2731.49 \pm 14.41 \mathrm{mg}$ eq. of gallic acid $/ 100 \mathrm{~g}$ of fresh matter, being a potential source of polyphenols, among which epigallocatechin gallate is included [47].

Banana leaves have been traditionally used as packaging for certain foods $[48,49]$. However, new applications for this residual biomass are being studied. Tarrés et al. [6], obtained lignocellulosic micro/nanofibers (LCMNF) where the results determined that this biomass has the potential to be used in paper manufacturing with lower production costs and higher yields than the cellulose nanofiber (CNF) production method. Regarding bioenergy production, Suhag et al. [27] reported a maximum bioethanol yield of $0.38 \mathrm{~g} / \mathrm{g}$ sugar, using dried banana leaf as a carbon source. The use of banana leaf extract has also been investigated. Chai et al. [50] determined that pressed banana leaf juice has a high glucose content $\left(16.6 \mathrm{gl}^{-1}\right)$, and from this result, they produced lipases. Tan et al. [7] used the juice extracted from banana frond (JEBF), which contains a total sugar of $14 \%$ with the amount of glucose $\left(18.9 \mathrm{gl}^{-1}\right)$, sucrose $\left(13.29 \mathrm{gl}^{-1}\right)$, and fructose $\left(15.63 \mathrm{gl}^{-1}\right)$ with a total volume of $0.331 \mathrm{JEBF} / \mathrm{kg}$ banana leaf with a theoretical yield of $65 \%$ for obtaining bioethanol. These results demonstrate the potential of banana leaf extract as a carbon source in the fermentation process of different microorganisms.

The valorization of waste biomass employing bio-based processes is a current trend [51-54]. However, there are different barriers to these developments. High production costs compared to products obtained from petroleum [53]. In addition, the variability of the quality, physical, structural, and chemical composition attributes of biomass [55], can technically and economically affect the operation of a biorefinery [56-58]. These attributes possibly vary due to certain factors such as environment, crop management, and location; however, this is not clear. Moreover, it is not known how this would affect the yield of fermentable sugars in the juice extracted from the banana leaves. 
This research analyzes how the quality attributes of banana leaves influence the concentration of its reducing sugars and their use as a carbon source for the production of bacterial nanocellulose (BNC) using a symbiotic culture of bacteria and yeast (SCOBY) [59,60]. SCOBY is a microbial consortium including yeast, acetic acid bacteria $(\mathrm{AAB})$, and lactic acid bacteria (LAB). In addition, SCOBY performs well in different media such as fruit juices, corn liquor, and media containing polyphenols at relatively low costs. It is used as a starter culture, together with black or green tea, to prepare Kombucha tea (KT) [60,61]. Green tea mainly provides four polyphenolic derivatives: (-)-epicatechin (EC), (-)-epicatechin-3-gallate (ECG), (-)-epigallocatechin (EGC) and (-)-epigallocatechin-3-gallate (EGCG). Likewise, black tea mainly provides two polyphenolic derivatives: theaflavin and thearubigins [61]. In addition, they are used as a source of nitrogen for fermentation [62].

KT has remarkable nutritional properties [62-65] and its consumption has increased in recent years [66-69]. For the preparation of this beverage, it is usually left to ferment for 7 to 14 days in static, aerobic conditions and the absence of light $[59,66]$. As a side stream of the fermentation, a biofilm containing BNC is obtained, known as tea fungus (TF), which is formed at the gas-liquid interface of the container [70-73]. BNC has applications in different sectors such as medicine, food, and cosmetology $[44,70,74]$, can be produced sustainably [69], and exhibits unique physical and biochemical properties [73]. However, it must be purified because, during fermentation, melanoidins are produced that are embedded in TF. Therefore, the biofilm must undergo physical or chemical treatment for its purification and subsequent characterization. Analyzes performed for BNC characterization include (i) thermogravimetric analysis (TGA), (ii) Fourier transform infrared (FTIR), and (iii) X-ray diffraction (XRD).

This work aims to: (i) determine the relationship between the morphological characteristics of banana leaves and the content of reducing sugars in the extracts obtained from them and, (ii) characterize the bacterial nanocellulose formed from banana leaf extract (BLE) as the sole carbon source for fermentation according to its physicochemical properties.

\section{Materials and Methods}

In the first part, the methods for analyzing the influence of certain factors of the banana leaf on the concentration of reducing sugars are indicated. In the second part, the procedure for obtaining BNC from BLE and kombucha tea as fermentation medium is described, and the methodology for the determination of the physicochemical properties of BNC by FTIR, TGA, and XRD.

\subsection{Determination of Factors Affecting the Concentration of Reducing Sugars in Banana Leaf Extract}

\subsubsection{Collection and Pretreatment of the Banana Leaf}

The samples were obtained from two banana exporting farms of the Cavendish subgroup (Musa acuminata) located in the Tres Postes (-1.983744822954974, -79.6114196251947) and Mariscal Sucre $(-2.1013910,-79.4960170)$, according to the Global Positioning System (GPS), a precinct in the province of Guayas-Ecuador. Thirty leaves per farm were collected from 30 plants in each farm, trying to choose green leaves without symptoms of necrosis, chlorosis, or insect perforations, and fully expanded from the third layer of leaves from the top in plants at the harvest stage. The samples were coded and transported in plastic bags to the laboratory. The leaves were washed with abundant running water and sponges to remove dust, organic matter, or residues and then left to dry in the sun for two hours for further processing. The banana leaves were stored at ambient conditions $\left(28^{\circ} \mathrm{C}\right.$ and $\left.1 \mathrm{~atm}\right)$.

\subsubsection{Banana Leaf Treatment and Reducing Sugars Estimation}

Before obtaining the BLE, some physical attributes such as fresh weight (g), length from the base of the leaf blade to the apex $(\mathrm{cm})$, and width at the widest part of the blade $(\mathrm{cm})$ were determined. In addition, indicators of leaf blade color and petiole type were determined visually on both the upper and lower sides. The color palette of the 
banana descriptor guide of the International Network for the Improvement of Banana and Plantain served as the basis for these descriptions [74]. Subsequently, the extract of each sample was obtained by passing the leaves three times through a mill called "trapiche", this equipment is made up of three rollers that press the banana leaf, like the one used to obtain sugar cane juice. Between each subsample, the "trapiche" was washed with abundant running water to minimize the influence of the extracts of other samples. The process of obtaining the extract was based on the methodology described in [7]. The juice from each subsample was collected in $2000 \mathrm{~mL}$ beakers and stored at low temperature $\left(4{ }^{\circ} \mathrm{C}\right)$. The extract from each subsample was collected in a $2000 \mathrm{~mL}$ Erlenmeyer flask and stored at a low temperature $\left(4^{\circ} \mathrm{C}\right)$. The extract samples were centrifuged at $3500 \mathrm{RPM}$ for $35 \mathrm{~min}$ at $-4^{\circ} \mathrm{C}$; a centrifuge was used (Thermo Scientific Sorvall ST 16R, Dreieich, Germany). Reducing sugars were analyzed by the 3,5-dinitrosalicylic acid method [75,76]. The calculation of the concentration of reducing sugars in the BLE was performed using the D-glucose standard curve.

\subsubsection{Data Analysis}

The relationship between the response variable: reducing sugar concentration and the factors: farm location, leaf weight, leaf length, leaf width, and volume of extract obtained, were analyzed using the scatter plot matrix; in addition, the Analysis of Variance and Linear Regression were used to determine the statistical model that best describes the process. All statistical tests were analyzed at $5 \%$ significance. RStudio software (version 4.0.3) was used.

\subsection{Juice Extracted from the Banana Leaf as a Means of Obtaining BNC}

\subsubsection{Culture Medium, Collection, and Purification of the Membrane}

To make the infusion, two liters of distilled water were heated for $15 \mathrm{~min}$ at $60^{\circ} \mathrm{C}$, followed by the addition of $20 \mathrm{gL}^{-1}$ of green tea (Sangay brand) for $15 \mathrm{~min}$. Then the temperature of the infusion was expected to drop to $25^{\circ} \mathrm{C}$ to be inoculated with $10 \%$ Kombucha mother tea ( $\mathrm{pH} 4,5^{\circ}$ Brix, and Specific Gravity 1.025). The SCOBY could include yeasts of the species Saccharomyces spp., Zygosaccharomyces spp., and Brettanomyces bruxellensis [59,77], acetic acid bacteria of the species Komagataeibacter spp, and lactic acid bacteria [77,78]. Next, BLEs were pasteurized for $15 \mathrm{~min}$ at $65{ }^{\circ} \mathrm{C}$, separately, and standardized at $4^{\circ}$ Brix. The fermentation process was carried out in $500 \mathrm{~mL}$ glass jars, previously sterilized and dried. The total volume of the ferment was $150 \mathrm{~mL}$, whose composition is $5 \mathrm{~g}$ of SCOBY, BLE $(70 \% v / v)$, and it was completed with the new Kombucha tea. The mouths of the vials were covered with surgical gauze and a plastic band. The ferments were stored at room temperature for 21 days, without shaking, following the methodology described in $[78,79]$.

Figure 1 shows the process diagram for obtaining BNC from the mixture of BLE, green tea infusion, vinegar, and SCOBY. The process is like that of the KT production, with BLE being used as the carbon source. During fermentation, a membrane is produced at the liquid-air interface of the ferment, which is harvested and washed with sodium hydroxide (3M) for purification, thus eliminating the presence of melanoidins and microorganisms. Finally, the membrane is washed with distilled water and repeatedly drained until neutralized $(\mathrm{pH} 7)[71,80]$. The residual $\mathrm{NaOH}$ solution is used to treat the residual bagasse from the leaf, and finally, this effluent is treated for final disposal. 


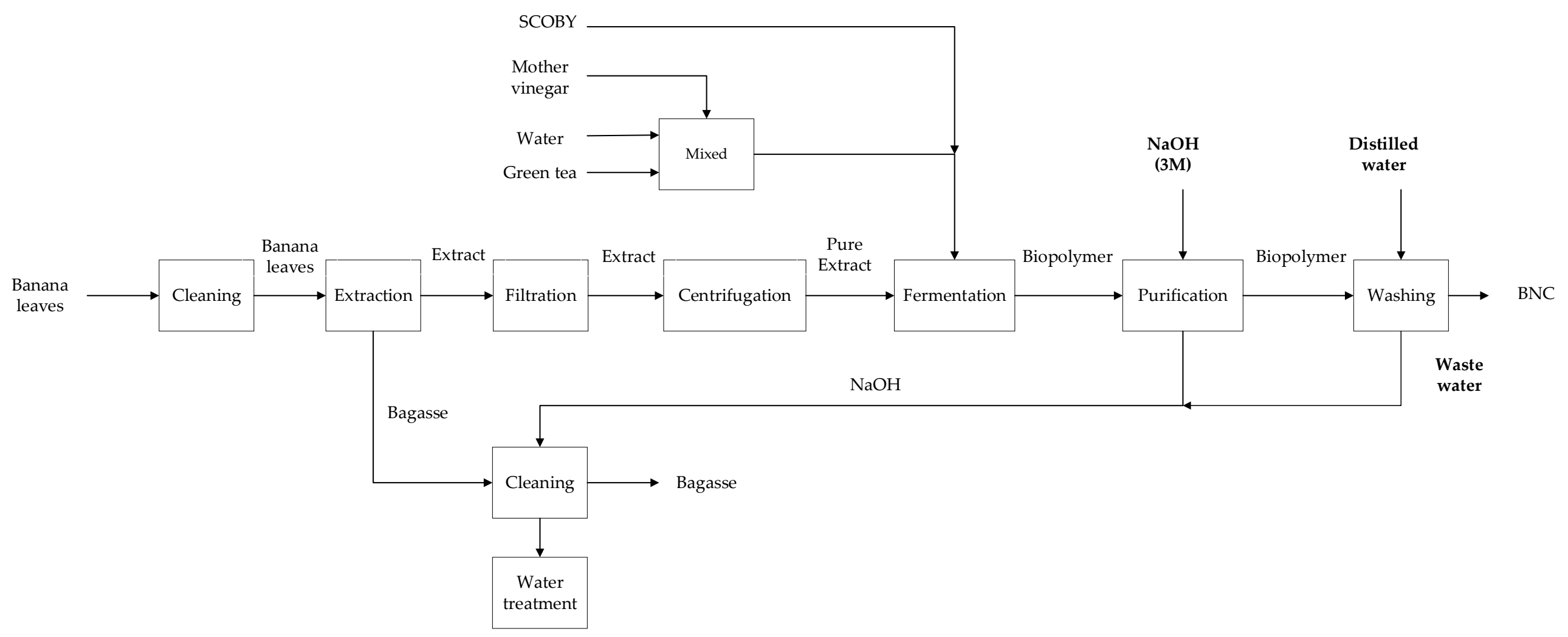

Figure 1. Process diagram for obtaining bacterial nanocellulose from banana leaf extract. 


\subsubsection{Acidity Level $(\mathrm{pH})$ of Kombucha Tea Based on BLE}

The acidity level of the ferment was monitored every $24 \mathrm{~h}$ with a digital $\mathrm{pH}$ meter (APERA instruments, LLC-PC60, EE.UU., Columbus, OH, USA).

\subsubsection{Determination of Fresh Weight and Thickness of BNC}

The polymeric membrane was harvested from the fermentation media every $24 \mathrm{~h}$ until day 21; then, the membrane was weighed on an analytical balance. Next, the thickness of the BNC formed in the fermentation media was measured with a vernier caliper at ten different points, and their values were averaged as described in [79-81].

\subsubsection{BNC Production}

The membrane formed at the liquid-gas interface of the ferment was harvested, dried on a glass plate at $105^{\circ} \mathrm{C}$ for $1 \mathrm{~h}$, and the dry weight was calculated. The volume of the culture medium was $150 \mathrm{~mL}$. Equations (1) and (2) were used to calculate the yield and production rate, respectively $[82,83]$.

$$
\begin{gathered}
\text { BNC yield }(\mathrm{g} / \mathrm{g})=\mathrm{W}_{\mathrm{S}} \cdot\left(\mathrm{S}_{\mathrm{o}}-\mathrm{S}_{\mathrm{e}}\right)^{-1}, \\
\text { BNC production rate }\left(\mathrm{gL}^{-1} \mathrm{~h}^{-1}\right)=\mathrm{W} \cdot(\mathrm{V} \cdot \mathrm{t})^{-1},
\end{gathered}
$$

where: Ws dry weight of BNC $(\mathrm{g}), \mathrm{S}_{\mathrm{o}}$ and $\mathrm{S}_{\mathrm{e}}$ mass of the substrate $(\mathrm{g})$ at the beginning and at the end of fermentation, respectively, $\mathrm{W}$ is the amount of BNC produced (g), V is the volume of culture medium $(\mathrm{L})$, and $\mathrm{t}$, is the time of culture fermentation $(\mathrm{h})$.

\subsubsection{Fourier Transform Infrared (FTIR)}

The membrane obtained on day 21 was purified with $\mathrm{NaOH}(3 \mathrm{M})$ to eliminate the presence of microorganisms and biochemical compounds present in the sample. Different treatment times were experimented with, $0,0.5,1.0,1.5$ and $2.0 \mathrm{~h}$. The treated samples were analyzed by FTIR. The spectra were recorded by the attenuated total reflectance (ATR) technique, in the range of 4000 to $600 \mathrm{~cm}^{-1}$, accumulating 32 spectra with a resolution of $4 \mathrm{~cm}^{-1}$ in a Spectrum GX spectrometer (Perkin Elmer, Waltham, MA, USA).

\subsubsection{Thermogravimetric Analysis (TGA)}

TGA was performed on the purified membrane. Standard TGA mode used nitrogen (99.99\%) as an equilibrium purge gas, flow rate $10 \mathrm{~mL} / \mathrm{min}$, nitrogen $(99.99 \%) 40 \mathrm{~mL} / \mathrm{min}$ as sample purge gas [78].

\subsubsection{X-ray Diffraction (XRD)}

Measurements were made using Cu K $\alpha 1$ radiation (wavelength $1.54059 \AA$ ), in parallel beam configuration, using the following system: the incident parallel slit was $5^{\circ}$, the incident slit was $0.2 \mathrm{~mm}$, the length-limiting slit was $10 \mathrm{~mm}$, the receiver parallel slit analyzer was $0.5^{\circ}$ and is operated at $45 \mathrm{kV}$ and $200 \mathrm{~mA}[44,63]$.

\section{Results and Discussion}

\subsection{Determination of Factors Affecting the Concentration of Reducing Sugars in Banana Leaf Extract}

Over the course of a month, the process of selection and classification of banana leaves was carried out, based on the following parameters (input variables): location of the farm, the time elapsed from harvesting to obtaining the extract, fresh weight of the leaf including petiole, length of the leaf including petiole, the width of the leaf, the color of the upper surface of the leaf and petiole canal. Additionally, the density of BLE was calculated, giving a value of $1020 \mathrm{~g} / \mathrm{mL}$ at $25^{\circ} \mathrm{C}$ and $1 \mathrm{~atm}$. Subsequently, following the steps described in Figure 1, the leaves are subjected to the extraction process, which is 
characterized by (output variables): extract volume, BLE yield per unit leaf mass, and reducing sugars concentration.

Table 1 shows the mean values of the quantitative variables concerning farm location. During the experiment, it was observed that as the storage time of banana leaves increased, physical characteristics such as weight and color of the upper surface varied. Regarding leaf length and width, these values coincide with those reported by Suada [84], who obtained the following results: leaf length $257.70 \pm 27.66 \mathrm{~cm}$, and leaf width $70.23 \pm 5.83 \mathrm{~cm}$. On the other hand, Tan et al. [7] determined that the percentage of juice extracted and filtered was $33 \%(v / p)$, and Chai et al. [50] estimated a percentage of $36 \%(v / p)$; however, in this work, a maximum average value of $13 \%(v / p)$ was calculated. In addition, it was determined that the Mariscal Sucre and Tres Postes samples reduced their BLE yield by $64.32 \%$ and $28.82 \%$ on the fifth day, respectively. There is no report so far on BLE performance at different times and environmental storage conditions. This study shows that storage at room temperature would produce large losses in juice yield and is certainly not a practice that should be carried out. In addition, the information obtained could serve as a baseline for future research that seeks to optimize the storage stage in biorefinery processes based on the use of banana leaves as raw material.

Table 1. Banana leaf sample indicators.

\begin{tabular}{|c|c|c|c|c|c|c|c|c|c|}
\hline Location & $\begin{array}{c}\text { Time } \\
\text { (day) }^{1}\end{array}$ & $\begin{array}{c}\text { Length } \\
\text { (cm) }\end{array}$ & $\begin{array}{l}\text { Width } \\
\text { (cm) }\end{array}$ & $\begin{array}{c}\text { Weight } \\
\text { (g) }{ }^{2}\end{array}$ & $\begin{array}{l}\text { BLE } \\
(\mathrm{mL})\end{array}$ & $\begin{array}{c}\text { Banana } \\
\text { Leaf } \\
\text { Color }\end{array}$ & $\begin{array}{l}\text { Canal } \\
\text { Petiole }\end{array}$ & $\begin{array}{l}\text { Yield } \\
\text { BLE } \\
(\% w / w)\end{array}$ & $\begin{array}{c}\text { Reducing } \\
\text { Sugars } \\
\left(\mathrm{gL}^{-1}\right)\end{array}$ \\
\hline \multirow{15}{*}{$\begin{array}{l}\text { Mariscal } \\
\text { Sucre }\end{array}$} & \multirow{3}{*}{1} & 283.00 & 102.00 & 1752.30 & 215.00 & $5 \mathrm{e} 7804$ & Wide & 12.52 & 18.00 \\
\hline & & 291.00 & 109.00 & 2204.00 & 270.00 & $5 \mathrm{e} 7804$ & Wide & 12.50 & 18.40 \\
\hline & & 299.00 & 100.00 & 1831.00 & 226.00 & 486904 & Wide & 12.59 & 17.60 \\
\hline & \multirow{3}{*}{2} & 244.00 & 100.00 & 656.56 & 83.00 & 719604 & Open & 12.89 & 13.50 \\
\hline & & 237.00 & 72.00 & 786.63 & 130.00 & 486904 & Wide & 16.86 & 17.60 \\
\hline & & 215.00 & 81.00 & 789.79 & 63.00 & 618604 & Wide & 8.14 & 16.40 \\
\hline & \multirow{3}{*}{3} & 263.00 & 100.00 & 1392.03 & 70.00 & $6 e 8904$ & Wide & 5.12 & 13.50 \\
\hline & & 256.00 & 100.00 & 1592.74 & 165.00 & b0dc04 & Wide & 10.57 & 13.50 \\
\hline & & 297.00 & 104.00 & 2131.50 & 375.00 & 486904 & Open & 17.95 & 18.00 \\
\hline & \multirow{3}{*}{4} & 290.00 & 106.00 & 1802.00 & 205.00 & 486904 & Straight & 11.60 & 13.50 \\
\hline & & 242.00 & 60.00 & 473.81 & 60.00 & $5 \mathrm{e} 7804$ & Open & 12.92 & 5.30 \\
\hline & & 273.00 & 82.00 & 954.00 & 75.00 & b0dc04 & Overlapping & 8.02 & 11.50 \\
\hline & \multirow{3}{*}{5} & 203.00 & 68.00 & 535.61 & 41.00 & 618604 & Wide & 7.81 & 9.80 \\
\hline & & 254.00 & 94.00 & 948.48 & 37.00 & bfd404 & Wide & 3.98 & 13.10 \\
\hline & & 309.00 & 88.00 & 1254.01 & 20.00 & bfd 404 & Wide & 1.63 & 9.40 \\
\hline \multirow{15}{*}{$\begin{array}{c}\text { Tres } \\
\text { postes }\end{array}$} & \multirow{3}{*}{1} & 256.00 & 108.00 & 1608.81 & 220.00 & 719604 & Open & 13.95 & 17.60 \\
\hline & & 268.00 & 105.00 & 1862.38 & 210.00 & $334 \mathrm{c} 04$ & Open & 11.50 & 17.60 \\
\hline & & 254.00 & 105.00 & 1790.47 & 245.00 & 3b5d04 & Wide & 13.96 & 16.00 \\
\hline & \multirow{3}{*}{2} & 286.00 & 92.00 & 1211.55 & 136.00 & b0dc04 & Open & 11.45 & 15.60 \\
\hline & & 269.00 & 101.00 & 1334.91 & 205.00 & 9bba04 & Open & 15.66 & 13.50 \\
\hline & & 266.00 & 99.00 & 1094.56 & 140.00 & dfeb04 & Wide & 13.05 & 17.60 \\
\hline & \multirow{3}{*}{3} & 258.00 & 95.00 & 1220.18 & 125.00 & 719604 & Wide & 10.45 & 17.20 \\
\hline & & 250.00 & 91.00 & 1384.55 & 155.00 & $9 \mathrm{bba} 04$ & Wide & 11.42 & 17.60 \\
\hline & & 205.00 & 78.00 & 971.91 & 120.00 & bfd 404 & Open & 12.59 & 13.90 \\
\hline & \multirow{3}{*}{4} & 268.00 & 89.00 & 1232.00 & 145.00 & 3b5d04 & Straight & 12.01 & 13.90 \\
\hline & & 263.00 & 103.00 & 1763.00 & 250.00 & $5 e 7804$ & Open & 14.46 & 17.60 \\
\hline & & 316.00 & 101.00 & 1774.00 & 130.00 & 486904 & Straight & 7.47 & 13.90 \\
\hline & \multirow{3}{*}{5} & 262.00 & 97.00 & 1340.25 & 150.00 & $6 e 8904$ & Open & 11.42 & 13.50 \\
\hline & & 260.00 & 106.00 & 970.60 & 90.00 & dfeb04 & Open & 9.46 & 13.50 \\
\hline & & 200.00 & 90.00 & 1350.37 & 95.00 & dfeb04 & Open & 7.18 & 13.50 \\
\hline
\end{tabular}

${ }^{1}$ Values obtained by averaging three replicates (leaves) per day. ${ }^{2}$ Values of the sum of the weight of the leaf blade, midrib, and petiole.

Concerning the concentration of reducing sugars, Oliveira et al. [85], determined that the water-soluble extractives of the banana leaf variety 'Dwarf Cavendish' are mainly composed of reducing sugars $(16.00 \%)$; this is due to the presence of starch in this morphological region of the plant. Chai et al. [50] determined that the content of fermentable sugars in banana leaf juice was $29.09 \mathrm{gL}^{-1}$, of which $55 \%$ is glucose. Tan et al. [7] found that banana leaf juice contained $14 \%$ of total sugars. In this study, the highest concentration of reducing sugars was found to be $18 \mathrm{gL}^{-1}$. The use of banana leaf extract eliminates the pretreatment stage such as acid/alkali hydrolysis and enzymatic hydrolysis that have been 
traditionally used [7,86-89], and replaces the costly glucose in the fermentation stage [50], making the process of obtaining reducing sugars sustainable.

In Figure 2, the box diagrams of each of the quantitative variables concerning the location are presented. Furthermore, the level of correlation of quantitative variables with respect to reducing sugars (RS) concentration can be graphically established. This is determined by observing the width of the ellipse; the greater the width, the less correlation will exist between the variables. In the case of the treatment days, thin ellipses are observed concerning the RS, indicating a strong correlation between the variables. However, the correlations of RS with the other variables are low.

In Table 1, the factors of the completely randomized Experimental Design model are analyzed. The model is shown in Equation (3).

$\mathrm{RS}\left(\mathrm{gL}^{-1}\right)=\mu+$ Time + Width + Weight + Length + Location + Color $_{\text {Leaf }}+\mathrm{Canal}_{\text {petiole }}+$ Error

The time and location factors have a highly significant effect, the petiole carcass type factor has a significant effect at $5 \%$, and finally, the leaf color factor is significant at $10 \%$ (Table 2).

Table 2. Anova of the linear regression model.

\begin{tabular}{cccccc}
\hline & Sum Sq & Df & F Value & Pr(>F) & \\
\hline Time & 81.421 & 1 & 38.0784 & 0.0000007555 & $* * *$ \\
\hline Banana leaf Length & 0.663 & 1 & 0.3099 & 0.5817536 & \\
\hline Location & 29.662 & 1 & 13.8719 & 0.0007806 & $* * *$ \\
\hline Weight of Banana leaf & 2.365 & 1 & 1.1062 & 0.3010395 & \\
\hline Banana leaf width & 2.050 & 1 & 0.9586 & 0.3351280 & \\
\hline Cod_color banana leaf & 39.652 & 10 & 1.8544 & 0.0917887 &. \\
\hline Canal_petiole & 23.151 & 3 & 3.6090 & 0.0240843 & $*$ \\
\hline Residue & 66.286 & 31 & & & \\
\hline Signif. codes: ${ }^{* * * \prime} 0.001 ;{ }^{* * \prime} 0.05 ;{ }^{\prime \prime} 0.1 ;{ }^{\prime \prime} 1$. & & & &
\end{tabular}

When analyzing these factors as a mixed regression model, the results obtained in Table 3 indicate that storage time and the location from which the sample is obtained are very significant factors affecting RS recovery. As the time elapsed from banana leaf collection to juice extraction increases, the RS concentration decreases by 1.134 units for each day. This indicates that prolonged storage under ambient conditions reduces the RS concentration, possibly due to the presence of microorganisms, such as fungi and bacteria, thus causing leaf biodeterioration. Similar results have been observed in sugarcane $[90,91]$. In this sense, Solomon [88] determined that most sugar factories in India have an average delay of 3 to 5 days between harvesting and milling, losing 1.0-1.3 sucrose units from the cane. He further indicates that this is due to factors such as humidity, ambient temperature, cane variety, invertase activities in the cane, and maturity stage. According to Wyse [90], in sugar beetroots, the reduction of sucrose content during postharvest is due to the continuous metabolic activity of living cells and the presence of endogenous enzymes capable of degrading sugars. It is important to note that no fungal growth was observed on banana leaves during this research. Likewise, it is observed that the location is a highly significant factor, i.e., when the leaves are collected from the Mariscal Sucre parish, the RS concentration is reduced by 2.07 units. This is due to the fact that the physicochemical characteristics of the biomass depend on the environment in which the crop is grown $[15,45]$. 
Table 3. Linear regression model coefficients.

\begin{tabular}{|c|c|c|c|c|c|}
\hline & Estimate & Std. Error & T Value & $\operatorname{Pr}(>|t|)$ & \\
\hline Intercepto & 22.705961 & 2.686999 & 8.450 & 0.00000000152 & $* * * *$ \\
\hline Time & -1.134597 & 0.183866 & -6.171 & 0.00000075549 & $* * *$ \\
\hline Banana leaf length & -0.004871 & 0.008750 & -0.557 & 0.581754 & \\
\hline Location (Mariscal Sucre) & -2.077652 & 0.557834 & -3.724 & 0.000781 & $* * *$ \\
\hline Weight of banana leaf & -0.001057 & 0.001005 & -1.052 & 0.301039 & \\
\hline Banana leaf width & 0.032122 & 0.032809 & 0.979 & 0.335128 & \\
\hline Cod_color[T.3b5d04] & -4.107568 & 1.623970 & -2.529 & 0.016729 & * \\
\hline Cod_color[T.486904] & -2.459556 & 1.830761 & -1.343 & 0.188875 & \\
\hline Cod_color[T.5e7804] & -2.711858 & 1.657470 & -1.636 & 0.111924 & \\
\hline Cod_color[T.618604] & -4.695788 & 1.965974 & -2.389 & 0.023190 & * \\
\hline Cod_color[T.6e8904] & -6.070761 & 1.946733 & -3.118 & 0.003908 & ** \\
\hline Cod_color[T.719604] & -4.512197 & 1.706995 & -2.643 & 0.012760 & * \\
\hline Cod_color[T.9bba04] & -3.166541 & 1.755115 & -1.804 & 0.080928 & . \\
\hline Cod_color[T.b0dc04] & -1.468817 & 2.420680 & -0.607 & 0.548416 & \\
\hline Cod_color[T.bfd404] & -4.646796 & 1.903255 & -2.441 & 0.020531 & * \\
\hline Cod_color[T.dfeb04] & -4.025819 & 1.792450 & -2.246 & 0.031973 & * \\
\hline Canal_petiole[Wide range] & 1.178651 & 0.589376 & 2.000 & 0.054347 & . \\
\hline Canal_petiole[Overlapping] & -1.495045 & 1.319143 & -1.133 & 0.265759 & \\
\hline Canal_petiole[Straight] & -0.963140 & 1.001189 & -0.962 & 0.343496 & \\
\hline
\end{tabular}

Mariscal Sucre and Tres Postes are located at an altitude of 10 and $9 \mathrm{~m}$ above sea level, respectively. Tres Postes has a fine, clayey soil texture and an ideal climate for banana and other food crops [91]. On the other hand, the Mariscal Sucre precinct has a fine soil type in $49 \%$ of the territory, and the rest is medium soil type. It also has a humid tropical Mediterranean climate with an average annual atmospheric temperature between 25 and $26^{\circ} \mathrm{C}$ [92]. Several factors can affect banana plant composition, including acidic $\mathrm{pH}$ soils, soil type, and excessive application of chemical fertilizers. These factors could be analyzed in future research.

On the other hand, it has been determined that leaf color varies with respect to color \#334c04 (Hex Color Codex), observing significant relationships concerning the decrease in RS concentration, which could be due to leaf senescence. Likewise, it was determined that the wide-ranging petiole type with erect margins positively influenced RS concentration by 1.18 units. These relationships between the different factors studied in this work have not been analyzed by other researchers.

To determine which variables are related to glucose concentration, the generalized linear model was used. The following statistical values were estimated; Residual standard error: 1.462 on 31 degrees of freedom, Multiple $R^{2}$ : 0.8423, Adjusted $R^{2}$ : 0.7507; F-statistic: 9.196 on 18 and 31 DF, $p$-value: 0.00000006194 . In this sense. The estimated parameters that have some degree of significance are expressed in Equation (4) with their respective coefficient.

$$
\begin{aligned}
& \mathrm{RS}\left(\mathrm{gL}^{-1}\right)=22.706-1.135 \cdot \text { Time }-2.078 \cdot \text { Location }_{\mathrm{MS}}-4.108 \cdot \text { Color }_{\mathrm{T} .3 \mathrm{~b} 5 \mathrm{~d} 04}-4.696 \cdot \text { Color }_{\mathrm{T} .618604}-6.071 \\
& \text {. } \text { Color }_{\mathrm{T} .618604}-4.512 \cdot \text { Color }_{\mathrm{T} .719604}-4.647 \cdot \text { Color }_{\mathrm{T} . \mathrm{bfd} 404}-3.167 \cdot \text { Color }_{\mathrm{T} .9 \mathrm{bba} 04}-4.06 \\
& \text {. } \text { Color }_{\mathrm{T} . \mathrm{dfeb} 04}+1.179 \cdot \text { Canal }_{\text {petiole-width }}
\end{aligned}
$$



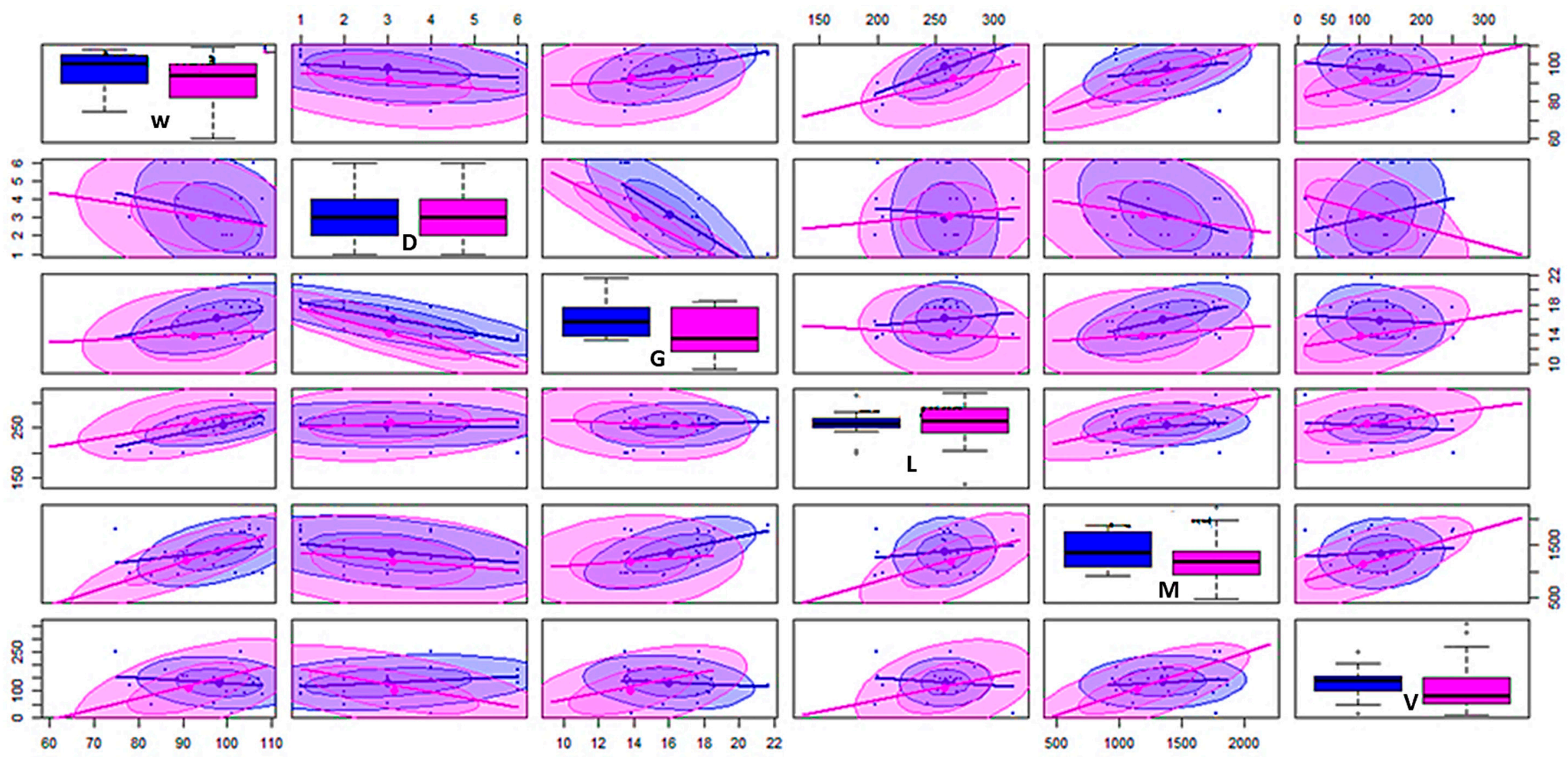

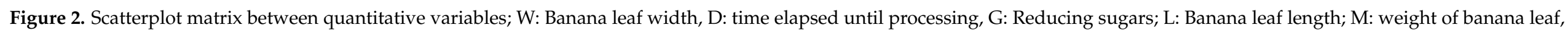
and V: volume extracted; Blue boxes: Mariscal Sucre, Pink boxes: Tres Postes. 


\subsection{Banana Leaf Extract as a Means to Obtain BNC}

\subsubsection{Culture Medium, Collection, and Purification of the Membrane}

For the fermentation stage, BLE $(70 \% v / v)$, mother vinegar $(10 \% v / v)$ were used as sugar sources. Green tea infusion provided nutrients containing nitrogen, vitamins, and minerals [65]. The culture medium resulted in a BNC polymer with a surface area equal to the dimensions of the container with the presence of melanoidins. The membrane is then purified with $\mathrm{NaOH}$. In addition, in this process, the leaf bagasse remains as a residue that undergoes a washing treatment with the residual solution generated in the BNC purification stage.

Different agricultural and food wastes have been used as a carbon source for the production of BNC [93-96]. With respect to the use of residual biomass from the banana value chain, rotten banana [83], as well as banana peel [44,81], have been used as a carbon source in the fermentation stage to obtain this biopolymer. In this work, BLE and Kombucha tea have been used for the first time as a medium for BNC biosynthesis.

In Figure 3, the products that are obtained from the banana leaf recovery process are shown. In Figure $3 a$ the juice of the extracted banana leaf is observed. Figure $3 b$ shows the membrane formed at the liquid-gas interface, whose dark color is due to the formation of melanoidins.

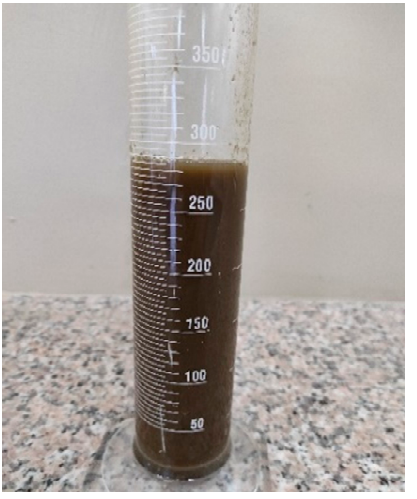

(a)

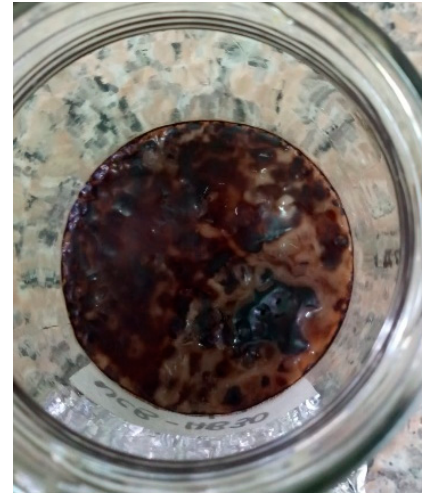

(b)

Figure 3. Bio-based process using banana leaf as raw material (a) Banana leaf extract; (b) BNC produced from BLE (70\%), and KT (20\%) after 21 days of fermentation.

\subsubsection{Acidity Level ( $\mathrm{pH}$ ) of Kombucha Tea Based on BLE}

The $\mathrm{pH}$ parameter of the fermentation process is closely related to microbial growth [59]. These assimilate the glucose present in the medium to carry out their various metabolic processes $[97,98]$. Therefore, due to these biochemical and metabolic processes, acetic and gluconic acid are generated, which lowers the $\mathrm{pH}$ of the fermentation medium [99-102]. In this sense, the lowest acceptable $\mathrm{pH}$ value should not be less than 3 [99]. Figure 4 shows the increase in $\mathrm{pH}$ at different fermentation times. The BLE-based Kombucha tea starts with a $\mathrm{pH}$ of 6.39 and reaches a $\mathrm{pH}$ of 3.5 after 21 days of fermentation.

\subsubsection{Determination of Fresh Weight and Thickness of BNC}

The main source of carbon during fermentation was the reducing sugars present in the banana leaf extract. The BNC is collected by simply removing it from the fermentation medium since this biopolymer forms a membrane that floats on the fermenting liquidgas interface [100]. This membrane serves as a physical barrier to protect the microbial consortium against external agents $[63,81,103]$, and is thought to help reduce the loss of oxygen from the medium caused by increased acidity [102]. As shown in Figure 5a, the results indicate that the weight of the CNB increases during the first 14 days, after which time the mass of CNB does not increase significantly. If the BNC weight increases significantly, it could precipitate to the bottom [79]. 


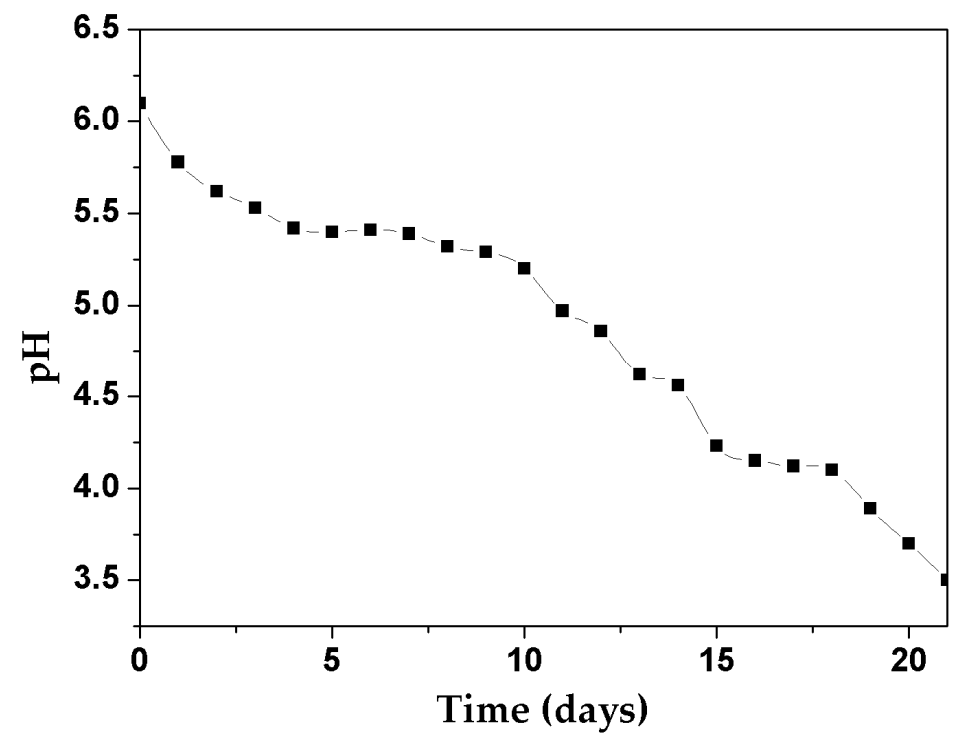

Figure 4. $\mathrm{pH}$ variation of kombucha tea based on banana leaf juice $(70 \%)$ at different fermentation times (days).

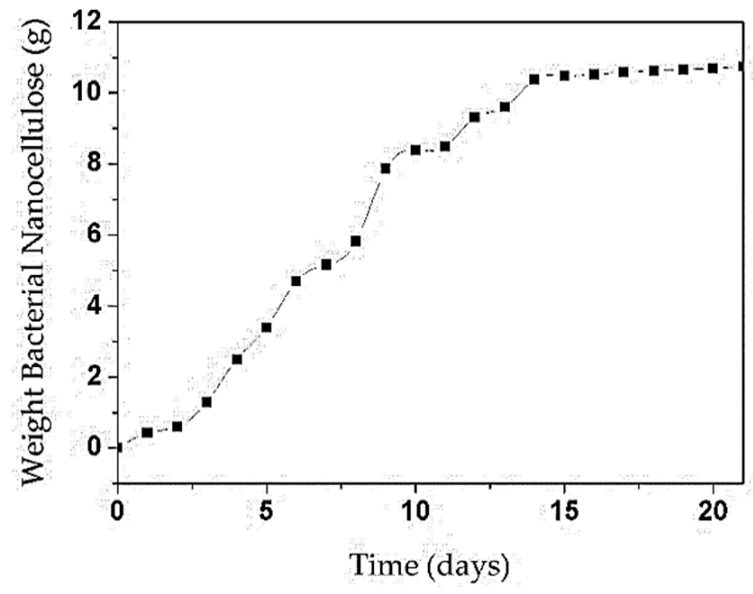

(a)

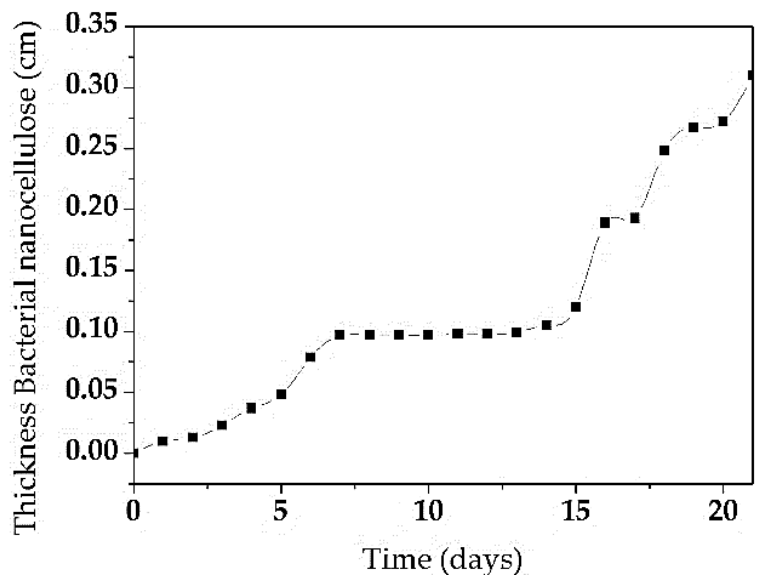

(b)

Figure 5. (a) Fresh weight of bacterial nanocellulose (g); (b) Membrane thickness (cm).

In Figure $5 b$, it is observed that the thickness of the membrane increases with time. These results are in agreement with those obtained in different studies $[81,98,104,105]$. Ramirez [104] determined that the optimum time for BNC recovery is 21 days.

\subsubsection{BNC Production}

BNC production and yield were estimated for the different fermentation times. Figure $6 \mathrm{a}$ shows that the yield increases until approximately day 15 , after which time it remains constant. This agrees with that indicated by some authors who observed better results in an average of 15 days $[81,96]$. Likewise, Figure $6 \mathrm{~b}$ shows that the production rate is highest at 11 days and decreases after. A limitation of this study is that the fermentation kinetics for the production of CNB has not been determined. 


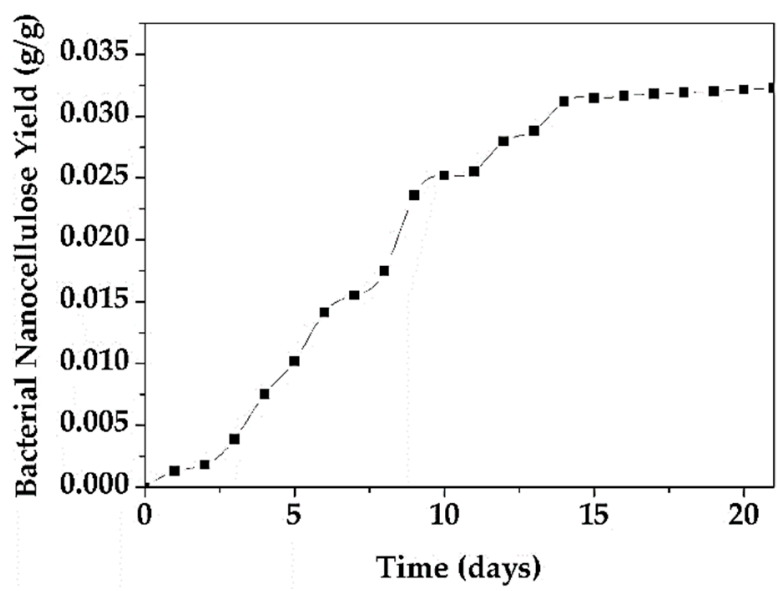

(a)

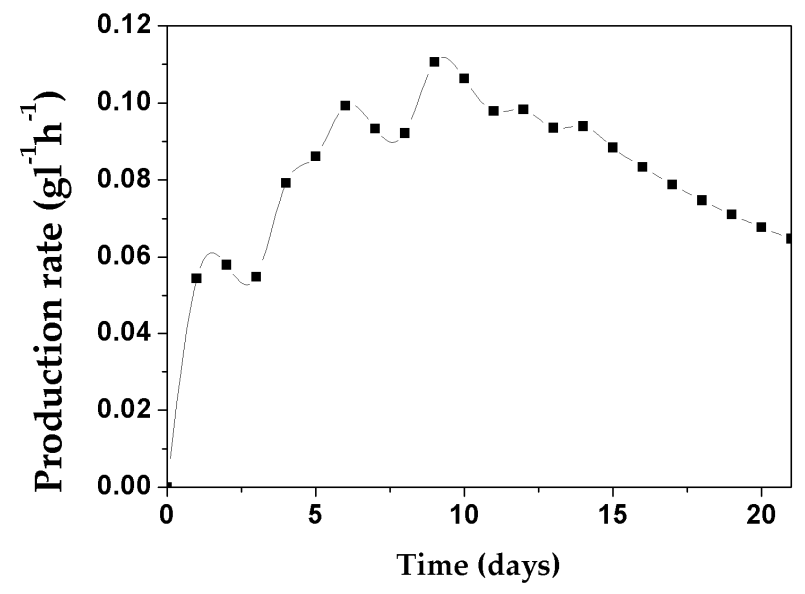

(b)

Figure 6. (a) Bacterial nanoceullose yield; (b) Bacterial nanoceullose production rate.

\subsubsection{Fourier Transform Infrared (FTIR)}

The BNC samples obtained from the fermentation were purified with $\mathrm{NaOH}(3 \mathrm{M})$, and the effect of treatment time was observed by FTIR. Figure 7 shows the FTIR profiles of BNC using BLE $(70 \%)$ at different treatment times with $\mathrm{NaOH}$. The spectra obtained showed typical BNC bands, which are the broad peak located in the region of $3200-3400 \mathrm{~cm}^{-1}[44,106,107]$, which corresponds to stretching vibrations of cellulose $\mathrm{OH}$ groups, while the peak around $2900 \mathrm{~cm}^{-1}$ is related to C-H stretching [71,79]. The peak at $1634 \mathrm{~cm}^{-1}$ is attributed to the $\mathrm{OH}$ bending of adsorbed water $[44,71,106,107]$. The peaks that appeared between $1055-1049 \mathrm{~cm}^{-1}$ correspond to C-O stretching at C3; C-C stretching; and C-O stretching at C6 [71,108]. The band at $896 \mathrm{~cm}^{-1}$ is attributed to C-O-C stretching at $\beta(1,4)$ glycosidic. Finally, the peak at $658 \mathrm{~cm}^{-1}$ is observed from $\mathrm{C}-\mathrm{OH}$ bonding out of plane vibrations $[44,71,79,107]$. The spectra with treatment times of 1.5 and $2 \mathrm{~h}$ show defined peaks corresponding to the cellulose I profile.

\subsubsection{Thermogravimetric Analysis (TGA)}

TGA was performed on the BNC sample treated with $\mathrm{NaOH}(3 \mathrm{M})$ for two hours. In Figure 8 , it is observed in the TGA spectrum that the BNC film loses mass around $100^{\circ} \mathrm{C}$. This could be due to the evaporation of the moisture present in the sample $[71,106,107]$. The pyrolysis of biosynthesized BNC in a medium with BLE $(70 \% v / v)$ presents the highest peak at $343.78^{\circ} \mathrm{C}$; this result is within the reported by different studies $[71,107,109]$. It is estimated that $\mathrm{BNC}$ starts at a higher temperature range $\left(340-360^{\circ} \mathrm{C}\right)$, associated with the complete degradation of BNCs, including depolymerization, dehydration, and decomposition of glucose [108].

\subsubsection{X-ray Diffraction (XRD)}

The diffractogram of BNC obtained from $\mathrm{BLE}(70 \% v / v)$ and purified with $\mathrm{NaOH}$ (3M) for $2 \mathrm{~h}$ is presented in Figure 9. In this sense, Santos et al. [109] indicate that the diffractogram of $\mathrm{BNC}$ has two dominant diffraction peaks, one between $14^{\circ}$ and $15^{\circ}$, and another between $22^{\circ}$ and $24^{\circ}$. Each of the peaks presents the two crystalline phases in cellulose, $\mathrm{I} \alpha$, and $\mathrm{I} \beta$.

In Figure 9, it is observed that the XRD curve presents some characteristic peaks of crystalline cellulose I at $2 \theta: 14.5^{\circ}, 16.5^{\circ}, 22.5^{\circ}$, and $34.5^{\circ}$. These results are in agreement with various studies [107-109]. 


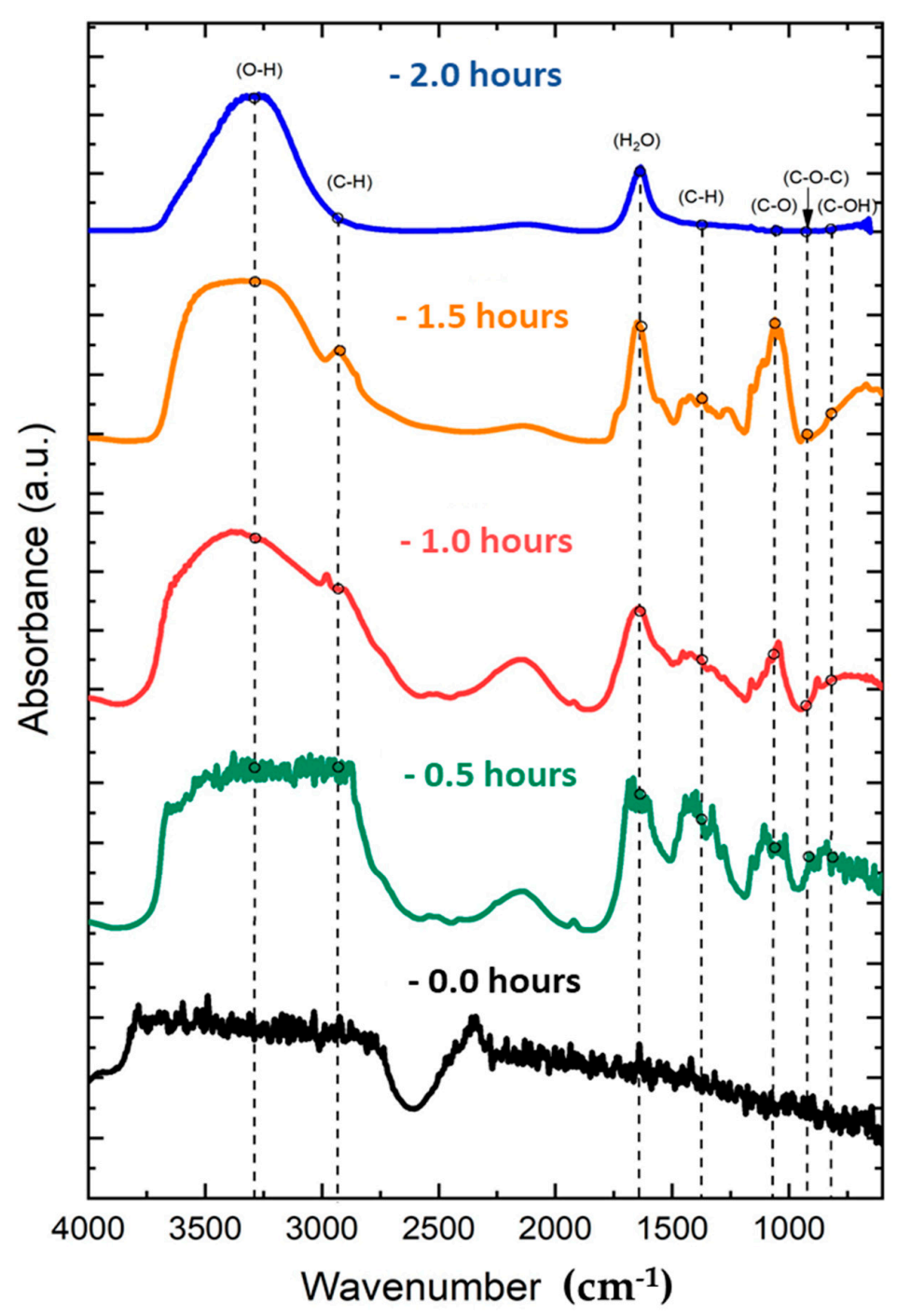

Figure 7. FTIR spectra of bacterial nanocellulose obtained from BLE $(70 \% v / v)$ at different treatment times with $\mathrm{NaOH}(3 \mathrm{M})$. Molecular assignments for all bands are shown.

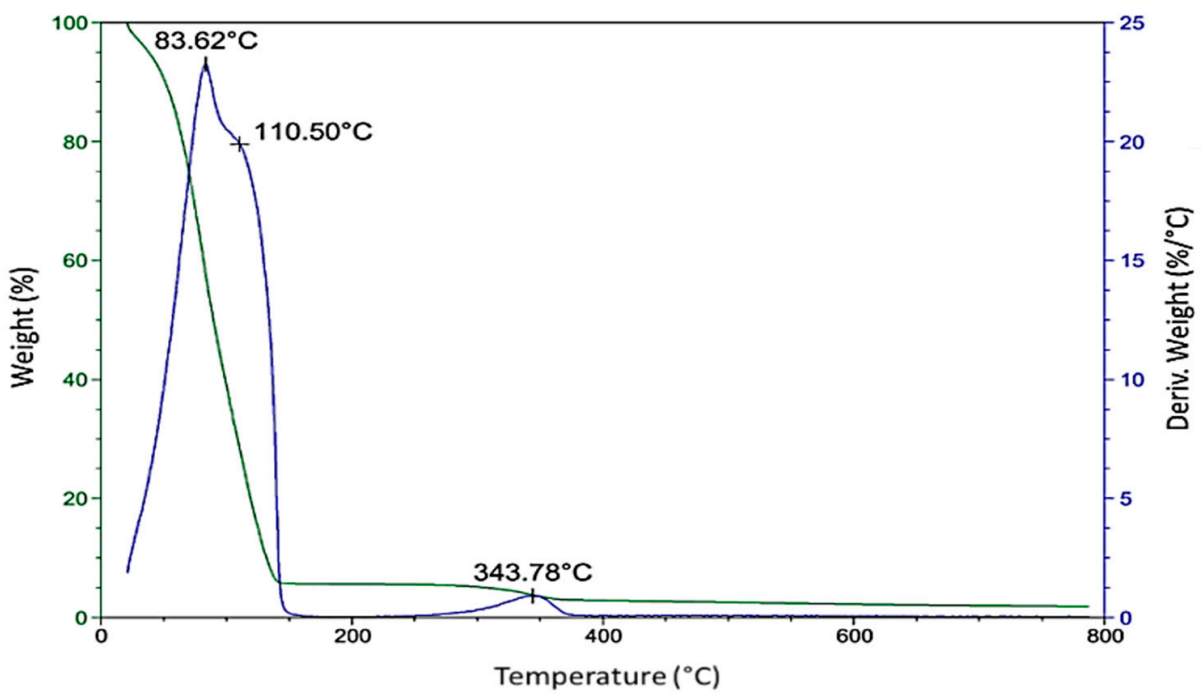

Figure 8. In green TGA curve and in blue curve derived from BNC produced from BLE (70\% v/v), treatment with $\mathrm{NaOH}(3 \mathrm{M})$ for two hours. 


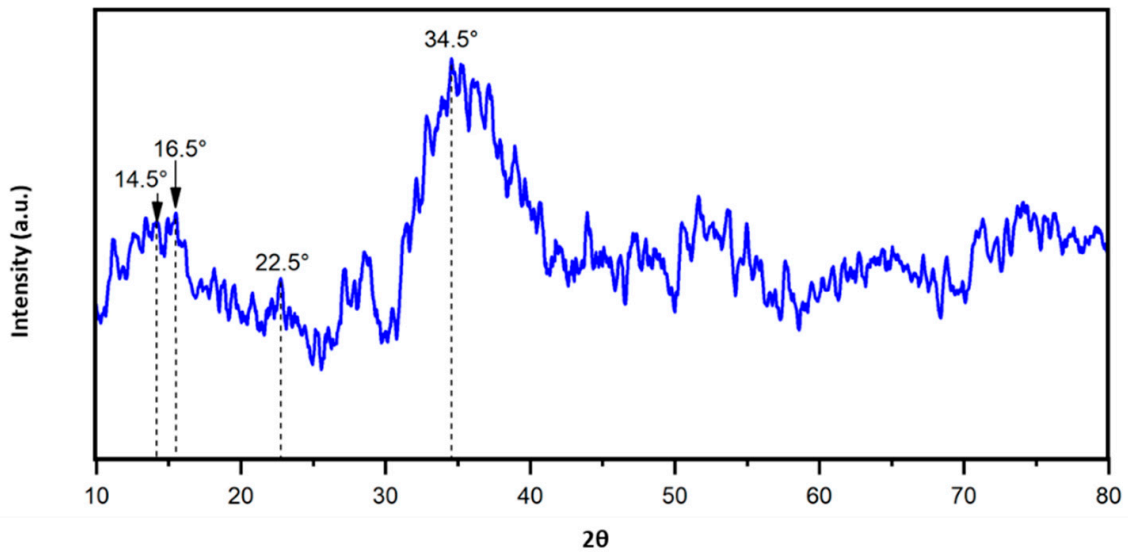

Figure 9. Diffractogram of BNC obtained from BLE $(70 \% v / v)$ and purified with $\mathrm{NaOH}$ for $2 \mathrm{~h}$.

\section{Conclusions}

Some feedstock factors can affect the yield of a bio-based production process. Testing these yields through predictive modeling can help in the development of sustainable biorefineries. In this sense, banana leaves are potential sources of reducing sugars that can be used in bio-based processes with a biorefinery approach. However, to implement this, it is necessary to know how storage time, feedstock source location, and physical characteristics relate to the process yield. It has been determined that banana leaf yield decreases by approximately $28.82 \%$ to $64.32 \%$ during storage times of three to five days. The linear model relating these factors to reducing sugar yield has an adjusted $\mathrm{R}^{2}$ of 0.7507. Previous research on banana leaf valorization had not considered these aspects of importance for industrial scale-up.

Furthermore, it has been shown that BNC films can be successfully obtained using banana extract as a carbon source and SCOBY as a starter culture. The $\mathrm{pH}$ change of the medium, the weight, and the thickness of BNC were evaluated. Yield $(0.031 \mathrm{~g} \mathrm{BNC} / \mathrm{g}$ fermentation medium) and production rate $\left(0.11 \mathrm{~g} \mathrm{~L}^{-1} \mathrm{~h}^{-1}\right)$ were also calculated. In addition, the physicochemical properties of BNC were analyzed by FTIR, XRD, and TGA, demonstrating the presence of Nanocellulose.

This approach based on the use of leaf extract to obtain bio-based compounds could contribute to the development of more sustainable processes and boost the creation of new value chains based on the concept of circular bioeconomy.

Author Contributions: Conceptualization, M.F.-C., A.D.R., S.P.-M., O.R.-B. and M.A.R.; Data curation, M.F.-C. and O.R.-B.; Formal analysis, M.F.-C. and O.R.-B.; Funding acquisition, M.F.-C., A.D.R., S.P.-M., H.R.B., M.O.-V. and M.A.R.; Investigation, M.F.-C.; Methodology, M.F.-C., A.D.R., S.P.-M. and O.R.-B.; Project administration, M.A.R.; Resources, H.R.B. and M.O.-V.; Supervision, A.D.R., S.P.-M., O.R.-B. and M.A.R.; Writing-original draft, M.F.-C. and A.D.R.; Writing-review \& editing, A.D.R., S.P.-M. and O.R.-B. All authors have read and agreed to the published version of the manuscript.

Funding: The authors would like to thank to Corporación Ecuatoriana para el Desarrollo de la Investigación y Academia-CEDIA for the financial support given to the present research, development, and innovation work through its CEPRA program, especially for the Study of the bioeconomic potential of glucose syrup obtained by enzymatic hydrolysis of banana rachis and leaf. A Circular Bioeconomy strategy in Ecuador. Project Code CEDIA-CEPRA XV-2021-02.

Institutional Review Board Statement: Not applicable.

Informed Consent Statement: Not applicable.

Data Availability Statement: Not applicable.

Acknowledgments: The authors would like to thank Juan Tirape for his collaboration in the collection of the samples. As well as to the students David Dager, Andrés Zeas, Nicole Pluas, Doménica Durán, Anthony Tubun, and Gabriel Quinto, for their support in the development of the experiments. 
Conflicts of Interest: The authors declare no conflict of interest.

\section{References}

1. Food and Agriculture Organization. Análisis del Mercado del Banano. Panorama General de Febrero de 2020. 2020. Available online: https:/ / www.fao.org/3/ca9212es/ca9212es.pdf (accessed on 10 June 2021).

2. Guerrero, A.B.; Muñoz, E. Life cycle assessment of second generation ethanol derived from banana agricultural waste: Environmental impacts and energy balance. J. Clean. Prod. 2018, 174, 710-717. [CrossRef]

3. Lamessa, K. Performance evaluation of banana varieties, through farmer's participatory selection. Int. J. Fruit Sci. 2021, 21, 768-778. [CrossRef]

4. Iriarte, A.; Almeida, M.G.; Villalobos, P. Carbon footprint of premium quality export bananas: Case study in Ecuador, the world's largest exporter. Sci. Total. Environ. 2014, 472, 1082-1088. [CrossRef]

5. Velasquez-Arredondo, H.I.; Ruiz-Colorado, A.A.; Junior, S.D.O. Ethanol production process from banana fruit and its lignocellulosic residues: Energy analysis. Energy 2010, 35, 3081-3087. [CrossRef]

6. Tarrés, Q.; Espinosa, E.; Domínguez-Robles, J.; Rodríguez, A.; Mutjé, P.; Delgado-Aguilar, M. The suitability of banana leaf residue as raw material for the production of high lignin content micro/nano fibers: From residue to value-added products. Ind. Crop. Prod. 2017, 99, 27-33. [CrossRef]

7. Tan, J.S.; Phapugrangkul, P.; Lee, C.K.; Lai, Z.-W.; Abu Bakar, M.H.; Murugan, P. Banana frond juice as novel fermentation substrate for bioethanol production by Saccharomyces cerevisiae. Biocatal. Agric. Biotechnol. 2019, 21, 101293. [CrossRef]

8. Anastopoulos, I.; Omirou, M.; Stephanou, C.; Oulas, A.; Vasiliades, M.A.; Efstathiou, A.M.; Ioannides, I.M. Valorization of agricultural wastes could improve soil fertility and mitigate soil direct N2O emissions. J. Environ. Manag. 2019, 250, 109389. [CrossRef] [PubMed]

9. Hashim, N.; Tai, C.W.T.W.; Wen, H.X.W.X.; Ismail, A.; Kong, K.W. Comparative evaluation of antioxidant properties and isoflavones of tempeh fermented in two different wrapping materials. Curr. Res. Nutr. Food Sci. J. 2018, 6, 307-317. [CrossRef]

10. Guimarães, G.G.F.; Cantú, R.R.; Scherer, R.F.; Beltrame, A.B.; De Haro, M.M. Banana crop nutrition: Insights into different nutrient sources and soil fertilizer application strategies. Rev. Bras. Ciência Solo 2020, 44. [CrossRef]

11. Gómez-García, R.; Campos, D.A.; Aguilar, C.N.; Madureira, A.R.; Pintado, M. Valorisation of food agro-industrial by-products: From the past to the present and perspectives. J. Environ. Manag. 2021, 299, 113571. [CrossRef] [PubMed]

12. Jimenez-Lopez, C.; Fraga-Corral, M.; Carpena, M.; García-Oliveira, P.; Echave, J.; Pereira, A.G.; Lourenço-Lopes, C.; Prieto, M.A.; Simal-Gandara, J. Agriculture waste valorisation as a source of antioxidant phenolic compounds within a circular and sustainable bioeconomy. Food Funct. 2020, 11, 4853-4877. [CrossRef] [PubMed]

13. Roibás, L.; Elbehri, A.; Hospido, A. Evaluating the sustainability of Ecuadorian bananas: Carbon footprint, water usage and wealth distribution along the supply chain. Sustain. Prod. Consum. 2015, 2, 3-16. [CrossRef]

14. Roibás, L.; Elbehri, A.; Hospido, A. Carbon footprint along the Ecuadorian banana supply chain: Methodological improvements and calculation tool. J. Clean. Prod. 2016, 112, 2441-2451. [CrossRef]

15. Ortiz-Ulloa, J.A.; Abril-González, M.F.; Pelaez-Samaniego, M.R.; Zalamea-Piedra, T.S. Biomass yield and carbon abatement potential of banana crops (Musa spp.) in Ecuador. Environ. Sci. Pollut. Res. 2020, 28, 18741-18753. [CrossRef]

16. Venkatramanan, V.; Shah, S.; Rai, A.K.; Prasad, R. Nexus between crop residue burning, bioeconomy and sustainable development goals over North-Western India. Front. Energy Res. 2021, 8, 392. [CrossRef]

17. Romero Bonilla, H.; Tinoco Gómez, O.K.; Dávila, D. Hidrólisis Enzimática de Residuos Agroindustriales del Banano Para la Obtención de Jarabe Glucosado Aplicando Tres Pretratamientos. 2015. Available online: https://www.redalyc.org/articulo.oa? $\mathrm{id}=81642256012$ (accessed on 30 October 2020).

18. Costa, S.; Rugiero, I.; Uria, C.L.; Pedrini, P.; Tamburini, E. Lignin degradation efficiency of chemical pre-treatments on banana rachis destined to bioethanol production. Biomololecules 2018, 8, 141. [CrossRef]

19. Lin, Z.; Huang, H.; Zhang, H.; Zhang, L.; Yan, L.; Chen, J. Ball milling pretreatment of corn stover for enhancing the efficiency of enzymatic hydrolysis. Appl. Biochem. Biotechnol. 2010, 162, 1872-1880. [CrossRef]

20. Świątek, K.; Gaag, S.; Klier, A.; Kruse, A.; Sauer, J.; Steinbach, D. Acid hydrolysis of Lignocellulosic Biomass: Sugars and furfurals formation. Catalysts 2020, 10, 437. [CrossRef]

21. Jayanna, N.K.K.; Basaiah, T.; Krishnappa, P. Effectiveness of Trichoderma viride and Phanerochaete chrysosporium NCIM 1197 pretreatment for second generation ethanol production from Areca Nut (Areca catechu L.) husk by separate hydrolysis and fermentation (SHF) process. Res. J. Biotechnol. 2021, 16, 95-104.

22. Alvira, P.; Tomás-Pejó, E.; Ballesteros, M.; Negro, M. Pretreatment technologies for an efficient bioethanol production process based on enzymatic hydrolysis: A review. Bioresour. Technol. 2010, 101, 4851-4861. [CrossRef] [PubMed]

23. Licari, A.; Monlau, F.; Solhy, A.; Buche, P.; Barakat, A. Comparison of various milling modes combined to the enzymatic hydrolysis of lignocellulosic biomass for bioenergy production: Glucose yield and energy efficiency. Energy 2016, 102, 335-342. [CrossRef]

24. Govumoni, S.P.; Koti, S.; Kothagouni, S.Y.; Linga, V.R. Evaluation of pretreatment methods for enzymatic saccharification of wheat straw for bioethanol production. Carbohydr. Polym. 2013, 91, 646-650. [CrossRef]

25. Singh, R.; Shukla, A.; Tiwari, S.; Srivastava, M. A review on delignification of lignocellulosic biomass for enhancement of ethanol production potential. Renew. Sustain. Energy Rev. 2014, 32, 713-728. [CrossRef] 
26. Shimizu, F.L.; Monteiro, P.Q.; Ghiraldi, P.H.C.; Melati, R.B.; Pagnocca, F.C.; de Souza, W.; Sant'Anna, C.; Brienzo, M. Acid, alkali and peroxide pretreatments increase the cellulose accessibility and glucose yield of banana pseudostem. Ind. Crop. Prod. 2018, 115, 62-68. [CrossRef]

27. Suhag, M.; Kumar, A.; Singh, J. Saccharification and fermentation of pretreated banana leaf waste for ethanol production. SN Appl. Sci. 2020, 2, 1-9. [CrossRef]

28. Damayanti, D.; Supriyadi, D.; Amelia, D.; Saputri, D.R.; Devi, Y.L.L.; Auriyani, W.A.; Wu, H.S. Conversion of Lignocellulose for bioethanol production, applied in bio-polyethylene terephthalate. Polymers 2021, 13, 2886. [CrossRef]

29. Cotana, F.; Cavalaglio, G.; Gelosia, M.; Coccia, V.; Petrozzi, A.; Ingles, D.; Pompili, E. A comparison between SHF and SSSF processes from cardoon for ethanol production. Ind. Crop. Prod. 2015, 69, 424-432. [CrossRef]

30. Sun, S.; Sun, S.; Cao, X.; Sun, R. The role of pretreatment in improving the enzymatic hydrolysis of lignocellulosic materials. Bioresour. Technol. 2016, 199, 49-58. [CrossRef]

31. Watkins, D.; Nuruddin, M.; Hosur, M.; Tcherbi-Narteh, A.; Jeelani, S. Extraction and characterization of lignin from different biomass resources. J. Mater. Res. Technol. 2015, 4, 26-32. [CrossRef]

32. Gonçalves Filho, L.C.; Fischer, G.A.A.; Sellin, N.; Marangoni, C.; Souza, O. Hydrolysis of banana tree pseudostem and secondgeneration ethanol production by saccharomyces cerevisae. J. Environ. Sci. Eng. 2013, 2, 65-69.

33. Sarkar, D.; Prajapati, S.; Poddar, K.; Sarkar, A. Production of ethanol by Enterobacter sp. EtK3 during fruit waste biotransformation. Int. Biodeterior. Biodegrad. 2019, 145, 104795. [CrossRef]

34. Linzmeyer, P.; Ramlow, H.; Souza, O.; Sellin, N.; Marangoni, C. Effects of by-products of fermentation of banana pseudostem on ethanol separation by pervaporation. Biotechnol. Prog. 2019, 35, e2830. [CrossRef] [PubMed]

35. Guerrero, A.B.; Aguado, P.L.; Sánchez, J.; Curt, M.D. GIS-Based Assessment of banana residual biomass potential for ethanol production and power generation: A case study. Waste Biomass Valorization 2016, 7, 405-415. [CrossRef]

36. Pazmiño-Hernandez, M.; Moreira, C.; Pullammanappallil, P. Feasibility assessment of waste banana peduncle as feedstock for biofuel production. Biofuels 2017, 10, 473-484. [CrossRef]

37. Atinkut, H.B.; Yan, T.; Zhang, F.; Qin, S.; Gai, H.; Liu, Q. Cognition of agriculture waste and payments for a circular agriculture model in Central China. Sci. Rep. 2020, 10, 1-15. [CrossRef]

38. Mboumboue, E.; Njomo, D. Biomass resources assessment and bioenergy generation for a clean and sustainable development in Cameroon. Biomass Bioenergy 2018, 118, 16-23. [CrossRef]

39. Phirke, N.; Patil, R.; Chincholkar, S.; Kothari, R. Recycling of banana pseudostem waste for economical production of quality banana. Resour. Conserv. Recycl. 2001, 31, 347-353. [CrossRef]

40. Teigiserova, D.; Hamelin, L.; Thomsen, M. Review of high-value food waste and food residues biorefineries with focus on unavoidable wastes from processing. Resour. Conserv. Recycl. 2019, 149, 413-426. [CrossRef]

41. Mufidah, E.; Prihanto, A.A.; Wakayama, M. Optimization of L-lactic acid production from banana peel by multiple parallel fermentation with Bacillus licheniformis and Aspergillus awamori. Food Sci. Technol. Res. 2017, 23, 137-143. [CrossRef]

42. Acevedo, S.A.; Carrillo, Á.J.D.; Flórez-López, E.; Grande-Tovar, C.D. Recovery of banana waste-loss from production and processing: A contribution to a circular economy. Molecules 2021, 26, 5282. [CrossRef]

43. Naranjo, J.M.; Cardona, C.A.; Higuita, J.C. Use of residual banana for polyhydroxybutyrate (PHB) production: Case of study in an integrated biorefinery. Waste Manag. 2014, 34, 2634-2640. [CrossRef]

44. Sijabat, E.K.; Nuruddin, A.; Aditiawati, P.; Purwasasmita, B.S. Synthesis and characterization of bacterial Nanocellulose from banana peel for water filtration membrane application. J. Phys. Conf. Ser. 2019, 1230, 012085. [CrossRef]

45. Gabhane, J.; William, S.P.; Gadhe, A.; Rath, R.; Vaidya, A.N.; Wate, S. Pretreatment of banana agricultural waste for bio-ethanol production: Individual and interactive effects of acid and alkali pretreatments with autoclaving, microwave heating and ultrasonication. Waste Manag. 2014, 34, 498-503. [CrossRef]

46. Fernandes, E.R.K.; Marangoni, C.; Souza, O.; Sellin, N. Thermochemical characterization of banana leaves as a potential energy source. Energy Convers. Manag. 2013, 75, 603-608. [CrossRef]

47. Sagrin, M.S.; Chong, G.H. Effects of drying temperature on the chemical and physical properties of Musa acuminata Colla (AAA Group) leaves. Ind. Crop. Prod. 2013, 45, 430-434. [CrossRef]

48. Rajagukguk, Y.V.; Arnold, M. Tempoyak: Fermented durian paste of Malay ethnic and its functional properties. Int. J. Gastron. Food Sci. 2021, 23, 100297. [CrossRef]

49. Erdiansyah, M.; Meryandini, A.; Wijaya, M.; Suwanto, A. Microbiological quality of tempeh with different wraps: Banana leaf versus plastic. J. Food Sci. Technol. 2021, 1-8. [CrossRef]

50. Chai, S.Y.; Abbasiliasi, S.; Lee, C.K.; Ibrahim, T.A.T.; Kadkhodaei, S.; Mohamed, M.S.; Hashim, R.; Tan, J.S. Extraction of fresh banana waste juice as non-cellulosic and non-food renewable feedstock for direct lipase production. Renew. Energy 2018, 126, 431-436. [CrossRef]

51. D'Amato, D.; Droste, N.; Allen, B.; Kettunen, M.; Lähtinen, K.; Korhonen, J.; Leskinen, P.; Matthies, B.D.; Toppinen, A. Green, circular, bio economy: A comparative analysis of sustainability avenues. J. Clean. Prod. 2017, 168, 716-734. [CrossRef]

52. Egea, F.J.; Torrente, R.G.; Aguilar, A. An efficient agro-industrial complex in Almería (Spain): Towards an integrated and sustainable bioeconomy model. New Biotechnol. 2018, 40, 103-112. [CrossRef] [PubMed]

53. Waramit, N. Developing a bioeconomy in Thailand. J. Int. Soc. Southeast Asian Agric. Sci. 2012, 18, 34-44. 
54. Duque-Acevedo, M.; Belmonte-Ureña, L.J.; Cortés-García, F.J.; Camacho-Ferre, F. Agricultural waste: Review of the evolution, approaches and perspectives on alternative uses. Glob. Ecol. Conserv. 2020, 22, e00902. [CrossRef]

55. Li, C.; Aston, J.E.; Lacey, J.A.; Thompson, V.S.; Thompson, D.N. Impact of feedstock quality and variation on biochemical and thermochemical conversion. Renew. Sustain. Energy Rev. 2016, 65, 525-536. [CrossRef]

56. Williams, C.L.; Westover, T.; Emerson, R.M.; Tumuluru, J.S.; Li, C. Sources of biomass feedstock variability and the potential impact on biofuels production. BioEnergy Res. 2016, 9, 1-14. [CrossRef]

57. Ng, H.S.; Kee, P.E.; Yim, H.S.; Chen, P.-T.; Wei, Y.-H.; Lan, J.C.-W. Recent advances on the sustainable approaches for conversion and reutilization of food wastes to valuable bioproducts. Bioresour. Technol. 2020, 302, 122889. [CrossRef]

58. Kapp, J.M.; Sumner, W. Kombucha: A systematic review of the empirical evidence of human health benefit. Ann. Epidemiol. 2019, 30, 66-70. [CrossRef] [PubMed]

59. Villarreal-Soto, S.A.; Beaufort, S.; Bouajila, J.; Souchard, J.-P.; Taillandier, P. Understanding Kombucha tea fermentation: A review. J. Food Sci. 2018, 83, 580-588. [CrossRef]

60. Amarasinghe, H.; Weerakkody, N.; Waisundara, V.Y. Evaluation of physicochemical properties and antioxidant activities of kombucha "Tea Fungus" during extended periods of fermentation. Food Sci. Nutr. 2018, 6, 659-665. [CrossRef] [PubMed]

61. Jayabalan, R.; Marimuthu, S.; Swaminathan, K. Changes in content of organic acids and tea polyphenols during kombucha tea fermentation. Food Chem. 2007, 102, 392-398. [CrossRef]

62. Dima, S.-O.; Panaitescu, D.-M.; Orban, C.; Ghiurea, M.; Doncea, S.-M.; Fierascu, R.C.; Nistor, C.L.; Alexandrescu, E.; Nicolae, C.-A.; Trică, B.; et al. Bacterial nanocellulose from side-streams of Kombucha Beverages production: Preparation and physical-chemical properties. Polymers 2017, 9, 374. [CrossRef]

63. Leal, J.M.; Suárez, L.V.; Jayabalan, R.; Oros, J.H.; Escalante-Aburto, A. A review on health benefits of kombucha nutritional compounds and metabolites. CyTA J. Food 2018, 16, 390-399. [CrossRef]

64. Pure, A.E.; Pure, M.E. Antioxidant and antibacterial activity of Kombucha Beverages prepared using banana peel, common nettles and black tea infusions. Appl. Food Biotechnol 2016, 3, 125-130.

65. Kim, J.Y.; Shin, H.J.; Kim, H.L.; Park, H.; Kim, P.K.; Park, S.; Kim, S.H. The Compositional and functional properties of Kombucha: A literature review. Food Eng. Prog. 2020, 24, 1-14. [CrossRef]

66. Mercado Global de Kombucha: Informes de la Industria. Available online: https://www.360researchreports.com/-globalkombucha-market-17759175 (accessed on 22 August 2021).

67. Kim, J.; Adhikari, K. Current trends in Kombucha: Marketing perspectives and the need for improved sensory research. Beverages 2020, 6, 15. [CrossRef]

68. Coelho, R.M.D.; de Almeida, A.L.; Amaral, R.Q.G.D.; da Mota, R.N.; de Sousa, P.H.M. Kombucha: Review. Int. J. Gastron. Food Sci. 2020, 22, 100272. [CrossRef]

69. Gupte, Y.; Kulkarni, A.; Raut, B.; Sarkar, P.; Choudhury, R.; Chawande, A.; Kumar, G.R.K.; Bhadra, B.; Satapathy, A.; Das, G.; et al. Characterization of nanocellulose production by strains of Komagataeibacter sp. isolated from organic waste and Kombucha. Carbohydr. Polym. 2021, 266, 118176. [CrossRef]

70. Semjonovs, P.; Ruklisha, M.; Paegle, L.; Saka, M.; Treimane, R.; Skute, M.; Rozenberga, L.; Vikele, L.; Sabovics, M.; Cleenwerck, I. Cellulose synthesis by Komagataeibacter rhaeticus strain P 1463 isolated from Kombucha. Appl. Microbiol. Biotechnol. 2017, 101, 1003-1012. [CrossRef] [PubMed]

71. Nirmal, N.; Pillay, M.N.; Mariola, M.; Petruccione, F.; van Zyl, W.E. Formation of dialysis-free Kombucha-based bacterial nanocellulose embedded in a polypyrrole/PVA composite for bulk conductivity measurements. RSC Adv. 2020, 10, 27585-27597. [CrossRef]

72. Ludwicka, K.; Kaczmarek, M.; Białkowska, A. Bacterial nanocellulose-A biobased polymer for active and intelligent food packaging applications: Recent advances and developments. Polymers 2020, 12, 2209. [CrossRef]

73. Jozala, A.F.; de Lencastre-Novaes, L.C.; Lopes, A.M.; Santos-Ebinuma, V.D.C.; Mazzola, P.G.; Pessoa, A., Jr.; Grotto, D.; Gerenutti, M.; Chaud, M.V. Bacterial nanocellulose production and application: A 10-year overview. Appl. Microbiol. Biotechnol. 2016, 100, 2063-2072. [CrossRef] [PubMed]

74. IPIGRI-International Plant Genetic Resources Institute. Descriptors for Banana (Musa spp.). 1996. Available online: https:// www.bioversityinternational.org/e-library/publications/detail/descriptors-for-banana-musa-spp/ (accessed on 16 June 2021).

75. Ingale, S.; Joshi, S.J.; Gupte, A. Production of bioethanol using agricultural waste: Banana pseudo stem. Braz. J. Microbiol. 2014, 45, 885-892. [CrossRef] [PubMed]

76. Miller, G.L. Use of Dinitrosalicylic acid reagent for determination of reducing sugar. Anal. Chem. 1959, 31, 426-428. [CrossRef]

77. Molina-Ramírez, C.; Castro, C.; Zuluaga, R.; Gañán, P. Physical characterization of bacterial cellulose produced by Komagataeibacter medellinensis using food supply chain waste and agricultural by-products as alternative low-cost feedstocks. J. Polym. Environ. 2017, 26, 830-837. [CrossRef]

78. Abol-Fotouh, D.; Hassan, M.A.; Shokry, H.; Roig, A.; Azab, M.S.; Kashyout, A.E.-H.B. Bacterial nanocellulose from agro-industrial wastes: Low-cost and enhanced production by Komagataeibacter saccharivorans MD1. Sci. Rep. 2020, 10, 1-14. [CrossRef]

79. Sijabat, E.K.; Nuruddin, A.; Aditiawati, P.; Purwasasmita, B.S. Optimization on the synthesis of bacterial nano cellulose (BNC) from banana peel waste for water filter membrane applications. Mater. Res. Express 2020, 7, 055010. [CrossRef]

80. Khan, H.; Saroha, V.; Raghuvanshi, S.; Bharti, A.K.; Dutt, D. Valorization of fruit processing waste to produce high value-added bacterial nanocellulose by a novel strain Komagataeibacter xylinus IITR DKH20. Carbohydr. Polym. 2021, 260, 117807. [CrossRef] 
81. Gomes, F.P.; Silva, N.H.; Trovatti, E.; Serafim, L.; Duarte, M.F.; Silvestre, A.; Neto, C.; Freire, C. Production of bacterial cellulose by Gluconacetobacter sacchari using dry olive mill residue. Biomass Bioenergy 2013, 55, 205-211. [CrossRef]

82. Khan, H.; Kadam, A.; Dutt, D. Studies on bacterial cellulose produced by a novel strain of Lactobacillus genus. Carbohydr. Polym. 2020, 229, 115513. [CrossRef]

83. C. Molina-Ramírez, J. C. Molina-Ramírez, J. Álvarez, R. Zuluaga, C. Castro, and P. Gañán, “A Novel Approach Using Conventional Methodologies to Scale up BNC Production Using Komagataeibacter medellinensis and Rotten Banana Waste as Alternative," Process. 2020, Vol. 8, Page 1469, vol. 8, no. 11, p. 1469, Nov. 2020. [CrossRef]

84. Suada, I.K. Short communication: The potential of various indigenous Trichoderma spp. to suppress Plasmodiophora brassicae the pathogen of clubroot disease on cabbage. Biodiversitas J. Biol. Divers. 2017, 18, 1424-1429. [CrossRef]

85. Oliveira, L.; Cordeiro, N.; Evtuguin, D.; Torres, I.; Silvestre, A. Chemical composition of different morphological parts from 'Dwarf Cavendish' banana plant and their potential as a non-wood renewable source of natural products. Ind. Crop. Prod. 2007, 26, 163-172. [CrossRef]

86. Kumar, P.; Sharma, R.; Ray, S.; Mehariya, S.; Patel, S.K.; Lee, J.-K.; Kalia, V.C. Dark fermentative bioconversion of glycerol to hydrogen by Bacillus thuringiensis. Bioresour. Technol. 2015, 182, 383-388. [CrossRef]

87. Souza, E.L.D.; Liebl, G.F.; Marangoni, C.; Sellin, N.; Montagnoli, M.D.S.; Souza, O. Bioethanol from fresh and dried banana plant pseudostem. Chem. Eng. Trans. 2014, 38, 271-276.

88. Solomon, S. Post-harvest deterioration of sugarcane. Sugar Tech. 2009, 11, 109-123. [CrossRef]

89. Eggleston, G. Deterioration of cane juice—sources and indicators. Food Chem. 2002, 78, 95-103. [CrossRef]

90. Wyse, R.E.; Dexter, S.T. Source of recoverable sugar losses in several sugarbeet varieties during storage. J. Sugarbeet Res. 1971, 16, 390-398. [CrossRef]

91. Cornejo Lago, J.M.; Diagnóstico Socioeconómico y Demográfico del Recinto Tres Postes—Provincia del Guayas. Período 2012-2013. 2015. Available online: http:/ / repositorio.ug.edu.ec/handle/redug/9160 (accessed on 14 November 2021).

92. GAD. Consejo de Planificación del GAD Parroquial Rural Mariscal Sucre. Available online: http://www.gadmariscalsucre.gob. ec/media/pdot_archivos/pdyot-MariscalSucre2015-2025.pdf (accessed on 20 October 2021).

93. Abdullah, N.A.; Rani, M.S.A.; Mohammad, M.; Sainorudin, M.H.; Asim, N.; Yaakob, Z.; Razali, H.; Emdadi, Z. Nanocellulose from agricultural waste as an emerging material for nanotechnology applications-An overview. Polimery 2021, 66, 157-168. [CrossRef]

94. Ivanišová, E.; Meňhartová, K.; Terentjeva, M.; Harangozo, L'.; Kántor, A.; Kačániová, M. The evaluation of chemical, antioxidant, antimicrobial and sensory properties of kombucha tea beverage. J. Food Sci. Technol. 2020, 57, 1840-1846. [CrossRef] [PubMed]

95. Sederavičiūtè, F.; Bekampienè, P.; Domskienè, J. Effect of pretreatment procedure on properties of Kombucha fermented bacterial cellulose membrane. Polym. Test. 2019, 78, 105941. [CrossRef]

96. Dutta, H.; Paul, S.K. Kombucha drink: Production, quality, and safety aspects. Prod. Manag. Beverages 2019, 259-288. [CrossRef]

97. Zou, C.; Li, R.-Y.; Chen, J.-X.; Wang, F.; Gao, Y.; Fu, Y.-Q.; Xu, Y.-Q.; Yin, J.-F. Zijuan tea-based Kombucha: Physicochemical, sensorial, and antioxidant profile. Food Chem. 2021, 363, 130322. [CrossRef]

98. Lončar, E.; Djurić, M.; Malbaša, R.; Kolarov, L.; Klašnja, M. Influence of working conditions upon Kombucha conducted fermentation of black tea. Food Bioprod. Process. 2006, 84, 186-192. [CrossRef]

99. Alderson, H.; Liu, C.; Mehta, A.; Gala, H.; Mazive, N.; Chen, Y.; Zhang, Y.; Wang, S.; Serventi, L. Sensory Profile of Kombucha Brewed with New Zealand Ingredients by Focus Group and Word Clouds. Fermentation 2021, 7, 100. [CrossRef]

100. Motaung, T.E.; Linganiso, L.Z. Critical review on agrowaste cellulose applications for biopolymers. Int. J. Plast. Technol. 2018, 22, 185-216. [CrossRef]

101. Tapias, Y.A.R.; Peltzer, M.A.; Delgado, J.F.; Salvay, A.G. Kombucha tea by-product as source of novel materials: Formulation and characterization of films. Food Bioprocess. Technol. 2020, 13, 1166-1180. [CrossRef]

102. Cakar, F.; Özer, I.; Aytekin, A.; Şahin, F. Improvement production of bacterial cellulose by semi-continuous process in molasses medium. Carbohydr. Polym. 2014, 106, 7-13. [CrossRef]

103. Tapias, Y.A.R.; Di Monte, M.V.; Peltzer, M.A.; Salvay, A.G. Bacterial cellulose films production by Kombucha symbiotic community cultured on different herbal infusions. Food Chem. 2021, 372, 131346. [CrossRef]

104. Mandal, A.; Chakrabarty, D. Isolation of nanocellulose from waste sugarcane bagasse (SCB) and its characterization. Carbohydr. Polym. 2011, 86, 1291-1299. [CrossRef]

105. Moreno, G.; Ramirez, K.; Esquivel, M.; Jimenez, G. Isolation and characterization of nanocellulose obtained from industrial crop waste resources by using mild acid hydrolysis. J. Renew. Mater. 2018, 6, 362-369. [CrossRef]

106. Mukwaya, V.; Yu, W.; Asad, R.A.; Yagoub, H. An environmentally friendly method for the isolation of cellulose nano fibrils from banana rachis fibers. Text. Res. J. 2016, 87, 81-90. [CrossRef]

107. Sharma, C.; Bhardwaj, N.K.; Pathak, P. Static intermittent fed-batch production of bacterial nanocellulose from black tea and its modification using chitosan to develop antibacterial green packaging material. J. Clean. Prod. 2021, 279, 123608. [CrossRef]

108. Santos, S.M.; Carbajo, J.M.; Gómez, N.; Ladero, M.; Villar, J.C. Modification of bacterial cellulose biofilms with Xylan polyelectrolytes. Bioengineering 2017, 4, 93. [CrossRef] [PubMed]

109. Jozala, A.F.; Pertile, R.; Dos Santos, C.A.; Santos-Ebinuma, V.; Seckler, M.; Gama, F.M.; Pessoa, A. Bacterial cellulose production by Gluconacetobacter xylinus by employing alternative culture media. Appl. Microbiol. Biotechnol. 2015, 99, 1181-1190. [CrossRef] 